\title{
The Influence of Whatsapp Application towards the Communication Ethics between Lecturers and Students
}

\author{
Mahfudlah Fajrie ${ }^{1}$, Dwi Agung Nugroho Arianto ${ }^{2}$ \\ Universitas Islam Nahdlatul Ulama Jepara, Indonesia ${ }^{1,2}$ \\ \{mahfudlahfajrie@unisnu.ac.id ${ }^{1}$, agung@unisnu.ac.id²\}
}

\begin{abstract}
This study to discuss the influence of WhatsApp application towards the communication ethics between lecture and students. The use of greetings, polite words and the right time to communicate sometimes are still not noticed by students when communicating with their lecturers. The approach used is quantitative with survey methods, data collection techniques consisting of questionnaires, interviews, and documentation with a sample of 84 people. The independent variable $(\mathrm{X})$ uses WhatsApp and variable dependent $(\mathrm{Y})$ is communication ethics. Indicators are taken from $\mathrm{CMC}$ theory and communication principles theory. The correlation test results show there is a significant and positive influence on the use of WhatsApp application towards the communication ethics between lecturers and students. Whatsapp is an important application for students and lecturers because it is considered to be very easy, fast, and cost-effective.
\end{abstract}

Keywords: WhatsApp; Communication Ethics; Lecturers and Students

\section{Introduction}

The most popular application for communication is WhatsApp. WhatsApp users around the world have recorded around 1 billion every day and there are also around 1.6 billion who use WhatsApp every month [1]. In the WhatsApp application, there are several advantages, including being easier for users to exchange messages, send pictures or videos, send sounds, send documents, to send locations where we are. WhatsApp application is one application that is very easy to use because it has a function that is not much different from mobile phones in general and the overall application cost is very low to one dollar per year [2], [3].

In education, the WhatsApp application is often used for communication. WhatsApp as a communication platform for various groups of students and teachers [4]. WhatsApp also has the influence of interpersonal communication between teachers and students [3], students can also learn intimate, authentic and fun [5]. WhatsApp has become a shared platform that allows increased accessibility, encourages collaboration, and increases motivation to take an active part in academic assignments [5], [6]. However, when a student wants to do thesis guidance to the lecturer, and the supervisor is difficult to find because of his busy schedule, then communication via telephone will be done, such as SMS, calling, or chatting through the 
WhatsApp application. Easy communication via WhatsApp that can be used anytime and anywhere sometimes makes students not pay attention to the right time and good sentences in communication. Every communication, there are ethics that must be considered. Especially communication between students and lecturers through WhatsApp.

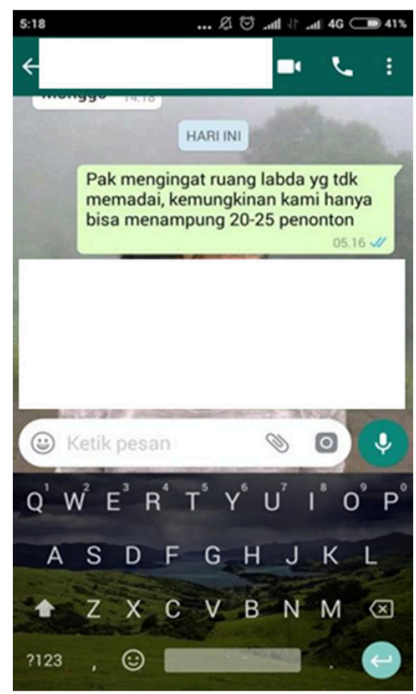

Fig. 1. Use of WhatsApp Text Messages (source: WhatsApp student)

Figure 1 above is one example of using WhatsApp Messanger done by students to lecturers at inappropriate times. In the picture, a student starts a chat at 05.16 WIB. It was still too early to start chatting about the campus. In the figure, the students also did not initiate the chat using greetings. This needs to be avoided and considered by students because not all lecturers always keep their student contact numbers.

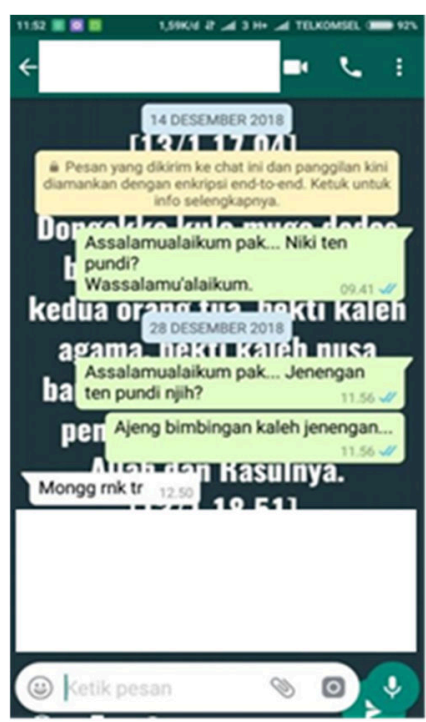

Fig. 2. Use of WhatsApp Text Messages by Students to Lecturers 
Communication ethics is very important. Ethics is a science that studies morals or character, the pros and cons of speech, and attitudes and actions [7]. As students who are part of Islamic tertiary institutions, they should understand the norms and ethics when communicating in cyberspace. Especially in the academic system of students, there are several ethics of communicating students with lecturers described in the section "Polite Behavior When Contacting Lecturers via Mobile". But it was ignored by the students. Thus the ethics of communicating students are sometimes inappropriate and incorrect as stated in the academic system.

Therefore, the researcher wants to conduct a study about the effect of using the WhatsApp application on the ethics of student communication with lecturers at the Da'wah and Communication Faculty of Unisnu Jepara. So the formulation of the problem in this study is: "How does the influence of using the WhatsApp application on the ethics of student communication with lecturers at the Faculty of Da'wah and Communication Unisnu Jepara?". The purpose of this study was to determine the effect of using the WhatsApp application on the ethics of student communication with lecturers at the Da'wah and Communication Faculty of Unisnu Jepara.

The benefits of this research are of two aspects, namely that it is hoped that this research can contribute to discussions or discourses about communication, and it is also useful to find out which factors have a significant effect on communication ethics over the use of new media such as the WhatsApp application. Practical benefits; contribute to providing input on the development of communication science in knowing and observing the ethics of communication between students and lecturers.

\section{Methodology}

This type of research is quantitative with survey methods, with two variables, namely the use of the WhatsApp application as an independent variable (X) and communication ethics as the dependent variable (Y). The focus of this research is to determine the effect of using the WhatsApp application on the ethics of student communication with lecturers at the Da'wah and Communication Faculty of Jepara Nahdlatul Ulama Islamic University, Indonesia. The population in this study were students. As for the number of students in the Da'wah and Communication Faculty of Jepara Nahdlatul Ulama Islamic University, Indonesia, there are 114 students with 50 male, 64 female.

Furthermore, the sample in this study used a simple random sampling technique and the number of samples was determined by the Isaac and Michael tables with an error rate of 5\%, so the samples in this study were 84 respondents. The number of samples was taken by focusing on students from 2015-2019 at random. Samples are part of the population. In addition to considering time, energy, and funding, the research sample will be determined by the researcher based on several things, including the consideration of problems, objectives, hypotheses, methods, and research instruments [8].

While data collection techniques with unstructured interviews, questionnaires with Likert scale calculations and documentation are used to determine the data of students who become research samples. Then, the data is analyzed, this includes the continued process of data processing to see how to interpret the data, then analyze the data from the results that already exist at the data processing stage [9]. In this study, researchers used the IBM SPSS Statistics version 23 application for processing data that had been obtained through a questionnaire. To find out the influence of the independent variable (WhatsApp use) on the dependent variable 
(Communication Ethics) on student and teacher communication, the analysis used is the product-moment correlation technique to find the correlation coefficient between the independent variable $(\mathrm{X})$ and the dependent variable $(\mathrm{Y})[10]$.

\section{Result and Discussion}

Computer-Mediated Communication (CMC) is a term used to communicate two or more people where they can interact with one another using computer facilities. According to Wood and Smith, Computer-Mediated Communication is identified as a study of how human behavior is maintained or changed through machines [11].

Computer-Mediated Communication (CMC) is human interaction through computer technology and is interrelated in the process of forming media for various purposes. Then Mediated Communication is a form of communication that uses any media to convey messages either through paper or letters. A set of computer-mediated communication is a person conveying messages through a digital media computer such as mobile phones and computers. With $\mathrm{CMC}$ a person can express feelings, but can not see the response, feedback, and body language of the communicant [12].

Technology or facilities on the internet used by CMC are Emails, server lists, and mailing lists; Newsgroups, bulletin boards, and blogs; Internet relay chat and instant messaging; Metaworld and visual chat; Personal homepages and webcams. For CMC support features on the smartphone itself, for example, LINE, KakaoTalk, Whatsapp, Blackberry Messenger, WeChat, Skype, and Google Talk. So WhatsApp is included in CMC.

Whereas in communication there are ethics that govern it. Communication ethics is a value or norm that must be considered in conducting a message delivery between communicators and also communicants. Ethical standards used in research include techniques, content, and communication objectives [13].

The presence of ethics in communication does not come suddenly, but the presence of ethics must be built by both parties. Richard L. Johansen has the opinion that a lot of people think that we must use ethics when communicating with other people. This is done as respect and courtesy in dealing with the other person. In the ethics of communication, there are six principles that are often used by people who are in a communication relationship, the principles include the principle of beauty, the principle of equality, the principle of goodness, the principle of justice, the principle of freedom, the principle of truth [14].

In this study, researchers used the CMC (Computer-Mediated Communication) theory for Whatsapp application usage variables and the principles of communication ethics for communication ethics variables. The following table is a rating indicator for each variable.

Table 1. Research Variable Assessment Indicators

\begin{tabular}{lll}
\hline \multicolumn{1}{c}{ Variable } & \multicolumn{1}{c}{ Dimension } & \multicolumn{1}{c}{ Indicator } \\
\hline Use the Whatsapp & Characteristic knowledge & Learn how to download the \\
application $(\mathrm{X})$ & WhatsApp application \\
& Learn how to use the features of \\
& the WhatsApp application \\
& Know the costs used to access \\
& the WhatsApp application \\
& The benefits & The advantage of the Whatsapp \\
& application is that it is a practical \\
& substitute for SMS at a low cost \\
\hline
\end{tabular}




\begin{tabular}{|c|c|c|}
\hline Variable & Dimension & Indicator \\
\hline \multirow{12}{*}{ Communication ethics (Y) } & & $\begin{array}{l}\text { The advantage of the WhatsApp } \\
\text { application is that it is easier to }\end{array}$ \\
\hline & Utilization & $\begin{array}{l}\text { The time used to access the } \\
\text { Whatsapp application } \\
\text { Use the Whatsapp application for } \\
\text { specific purposes }\end{array}$ \\
\hline & The principle of beauty & Hospitality \\
\hline & & Smile \\
\hline & & Greeting \\
\hline & Principle of equality & Non-discriminatory behavior \\
\hline & The principle of kindness & Respect \\
\hline & & Affection \\
\hline & The principle of justice & $\begin{array}{l}\text { Fair proportionally (not taking } \\
\text { something that belongs to } \\
\text { someone else) }\end{array}$ \\
\hline & Freedom principle & The right to do something \\
\hline & & The right not to do something \\
\hline & Principle of truth & Proof of truth to a discussion \\
\hline
\end{tabular}

From the results of questionnaire data processing from 84 samples found the productmoment correlation test results are used to determine whether there is a close relationship between variables. As for knowing whether there is a close relationship between variables, one can see the Pearson correlation value. Correlation values range from 1 to -1 if values close to 1 or -1 means the relationship between the two variables is getting stronger. Conversely, if the value is close to 0 means the relationship between the two variables is getting weaker. The following is the product-moment correlation test table:

Table 2. Product Moment Correlation Test Results

\begin{tabular}{|c|c|c|c|}
\hline \multicolumn{4}{|c|}{ Correlations } \\
\hline & & $\begin{array}{c}\text { Use the Whats App C } \\
\text { application }\end{array}$ & $\begin{array}{c}\text { Communication } \\
\text { ethics }\end{array}$ \\
\hline \multirow{3}{*}{$\begin{array}{l}\text { Use the WhatsApp } \\
\text { application }\end{array}$} & Pearson Correlation & 1 &, $317 * *$ \\
\hline & Sig. (1-tailed) & &, 002 \\
\hline & $\mathrm{N}$ & 84 & 84 \\
\hline \multirow[t]{3}{*}{ Communication ethics } & Pearson Correlation &, $317 * *$ & 1 \\
\hline & Sig. (1-tailed) & 002 & \\
\hline & $\mathrm{N}$ & 84 & 84 \\
\hline
\end{tabular}

Pearson correlation value in the table is 0.317 with a significant product-moment correlation coefficient of 0.002 . With a value of 0.317 , then it is close to 0 . This shows the close relationship between the variable use of the Whatsapp application to the variable of communication ethics. However, because the value is close to 0 , the closeness of the two variables is getting weaker. So, the correlation between the variable use of the Whatsapp application to the variable of communication ethics is stated positive and the relationship is one-way.

Then testing the hypothesis in this study is to test the hypothesis that the researchers propose, namely by seeing whether the hypothesis (Ha) submitted by the researcher is accepted or rejected. There are two references that can be used in making hypothesis test 
decisions. First, based on the significance value $<$ probability 0.05 , there is the influence of the use of the Whatsapp $(\mathrm{X})$ variable on the communication ethics variable $(\mathrm{Y})$ means the hypothesis is accepted (Ha). Second, if the significance value $>$ probability 0.05 , then there is no influence of the use of the Whatsapp $(\mathrm{X})$ variable on the communication ethics variable $(\mathrm{Y})$ means the hypothesis is rejected (Ho).

The hypothesis in this study is Ha: There is an influence of using Whatsapp on the ethics of communication between students and lecturers. Hypothesis testing in this study uses regression analysis techniques with the IBM SPSS Statistics 23 program.

Table 3. Hypothesis Test

\begin{tabular}{|c|c|c|c|c|c|c|}
\hline \multicolumn{7}{|c|}{ Coefficients } \\
\hline & \multirow[b]{2}{*}{ Model } & \multicolumn{2}{|c|}{$\begin{array}{l}\text { Unstandardized } \\
\text { Coefficients }\end{array}$} & \multirow{2}{*}{$\begin{array}{c}\begin{array}{c}\text { Standardized } \\
\text { Coefficients }\end{array} \\
\text { Beta }\end{array}$} & \multirow[b]{2}{*}{$\mathbf{T}$} & \multirow[b]{2}{*}{ Sig. } \\
\hline & & B & Std. Error & & & \\
\hline 1 & (Constant) & 26,130 & 2,994 & & 8,726 & 000 \\
\hline & $\begin{array}{l}\text { Use the WhatsApp } \\
\text { application }\end{array}$ &, 363 &, 120 &, 317 & 3,028 &, 003 \\
\hline
\end{tabular}

a. Dependent Variable: Communication Ethics

Based on the table, it was found that the significance value (Sig) of the Whatsapp (X) application usage variable was $0.003<$ probability 0.05 so it can be concluded that Ha was accepted. This means that there is an influence on the use of the Whatsapp application (variable $\mathrm{X}$ ) on communication ethics (variable $\mathrm{Y}$ ).

As for knowing what percentage of the effect of using the Whatsapp application on communication ethics is to test the coefficient of determination. The value of the coefficient of determination test can be determined by looking at the R Square column in the following table:

Table 4. Coefficient of Determination Test Results

\begin{tabular}{ccccc}
\hline \multicolumn{5}{c}{ Model Summary } \\
\hline Model & R & R Square & $\begin{array}{c}\text { Adjusted } \\
\text { R Square }\end{array}$ & $\begin{array}{c}\text { Std. Error of } \\
\text { the Estimate }\end{array}$ \\
\hline 1 &, $317 \mathrm{a}$ &, 101 &, 090 & 4,773 \\
\hline
\end{tabular}

a. Predictors: (Constant), Use the WhatsApp application

b. Dependent Variable: Communication ethics

From the table above it can be explained that the R Square column obtained a value of 0.101 or $10.1 \%$. This shows that the Whatsapp application has an influence on communication ethics of $10.1 \%$, while $89.9 \%$ comes from the contribution of other variables not examined in this study.

From statistical data, it can be explained that almost all students of the Da'wah and Communication Faculty of Jepara Nahdlatul Ulama Islamic University, Indonesia use the Whatsapp application as a means of communication because it is considered easier, more practical, and economical. This indicates that the Whatsapp application is very familiar in the campus environment. Some factors that cause students to use the Whatsapp application on their smartphones are because the Whatsapp application offers some ease in terms of communication, such as exchanging documents, photos, data, videos.

How to get the Whatsapp application is very easy to do, namely by downloading the application in PlayStore for Android users and in the App Store for iPhone users. In addition, the Whatsapp application is very easy to use and can be connected for 24 hours as long as it is 
connected to the internet network and the costs used are more economical than regular SMS. This is the reason why one of the students likes to use it. Besides being able to be used on smartphones, the application can also be used on the web. Whatsapp application has the latest features that can facilitate the work and can also be used as mere entertainment like making news in the story. However, on the other hand, communication via Whatsapp raises the ethics of communication that is not good.

Some ethical principles of communication commonly used by students who communicate with lecturers through Whatsapp such as introducing themselves when chatting, using smile emoticons and saying greetings first and students should not discriminate between lecturers with one another, students must still have good ethics when communicating through the media. Students must use polite language, not use abbreviations and words that are unclear or difficult to understand. In addition to good and polite language, another thing to note is the right time when communicating. The right time to communicate with the lecturer is at work hours 08.00 - 16.00 WIB.

The things that are often complained by one of the lecturers about the WhatsApp application are like students being lazy to meet face to face and talk to the lecturer. They are more convenient and easier to use the chat. Some students also communicate without saying hello or introducing themselves. This results in a confused lecturer to reply because he did not know who had contacted him. From the results above we can know that the CMC (ComputerMediated Communication) theory and the principles of communication ethics can prove that there is an influence on the use of the Whatsapp application on the ethics of communication between students and lecturers.

\section{Conclusion}

Based on the results of the study there is a significant and positive influence between Whatsapp applications on communication ethics between students and lecturers. This is evidenced by the results of the correlation test using product-moment correlation analysis with a sample of 84 students showing the acquisition of a correlation coefficient of 0.317 with a significance value of 0.002 . But the relationship between the two variables is weak because of the acquisition of a correlation coefficient of 0.317 which is close to 0 .

With the advent of various social media applications, they can be used freely for communication activities, causing students to access and use them more often to facilitate communication. One application that is intended and often used by students is the Whatsapp application because the use of the Whatsapp application is very easy, fast, and cost-effective. This causes students to require to have the application on their smartphone. Students often communicate with lecturers via Whatsapp to ask about lecture info, course assignments and discussions.

\section{References}

[1] D. H. Jayani, "Whatsapp, Pengirim Pesan Paling Populer di Dunia," 2019. [Online]. Available: https://databoks.katadata.co.id/datapublish/2019/05/23/whatsapp-pengirimpesan-paling-populer-di-dunia. [Accessed: 26-Oct-2019].

[2] D. Bouhnik and M. Deshen, "WhatsApp Goes to School: Mobile Instant Messaging between Teachers and Students," J. Inf. Technol. Educ. Res., vol. 13, pp. 217-231, 2014. 
[3] K. Church and R. De Oliveira, "What's up with WhatsApp ? Comparing Mobile Instant Messaging Behaviors with Traditional SMS," Mob. HCI 2013-Collaboration Commun., pp. 352-361, 2013.

[4] Y. Fischer, "The Facebook is Dead- Long Live WhatsApp," De Marker, 2013.

[5] P. Rambe and A. Bere, "Using mobile instant messaging to leverage learner participation and transform pedagogy at a South African University of Technology," Br. J. Educ. Technol., vol. 44, no. 4, pp. 544-561, 2013.

[6] P. Rambe and C. Chipunza, "Using mobile devices to leverage student access to collaboratively-generated re-sources: A case of WhatsApp instant mes-saging at a South African University," Int. Conf. Adv. Inf. Commun. Technol. Educ., no. August 2013, 2013.

[7] Rahmadaniah, "Etika Komunikasi Karyawan dalam Memberikan Pelayanan kepada Pelanggan di PT. Globalindo 21 Express Cabang Samarinda," eJournal Ilmu Koтиn., vol. 2, no. 2, pp. 353-369, 2014.

[8] D. Darmawan, Metode Penelitian Kuantitatif. Bandung: PT. Remaja Rosdakarya, 2014.

[9] B. Prasetyo and L. M. Jannah, Metode Penelitian Kuantitatif, 1st ed. Jakarta: Rajawali Pers, 2011.

[10] M. Tahir, Pengantar Metodologi Penelitian Pendidikan. Makasar: Universitas Muhammadiyah Makasar, 2011.

[11] S. H. Arnus, "Computer Mediated Communication (CMC) Pola Baru Berkomunikasi," Al-Munzir, vol. 8, no. 2, pp. 275-289, 2015.

[12] G. Riva and C. Galimberti, "Computer-mediated communication : identity and social interaction in an electronic environment," Genet. Soc. Gen. Psychol. Monogr., vol. 124, no. November, pp. 434-464, 1998.

[13] K. El Karimah and U. Wahyudin, Filsafat dan Etika Komunikasi. Bandung: Widya Padjajaran, 2010.

[14] E. Harapan and S. Ahmad, Komunikasi Antarpribadi. Depok: Rajawali Pers, 2019. 